\title{
Landslide susceptibility assessment at Kathmandu Kyirong Highway Corridor in pre-quake, co-seismic and post-quake situations
}

Susmita DHAKAL ${ }^{1,2,3}$ iD http://orcid.org/oooo-0oo2-3025-5501; e-mail: susmita.dhakal@gmail.com

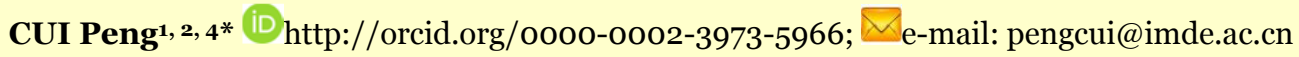
SU Li-jun', 2, 4, 5 iD http://orcid.org/oooo-ooo1-9972-4698; e-mail: sulijun1976@163.com Olga MAVROULI6 iD http://orcid.org/oooo-ooo3-1909-6113; e-mail: o.c.mavrouli@utwente.nl ZOU Qiang1 iD http://orcid.org/oooo-0oo3-0029-8532; e-mail: zouqiang@imde.ac.cn ZHANG Jian-qiang1 (D) https://orcid.org/oooo-0oo3-3908-1082; e-mail: zhangjq@imde.ac.cn

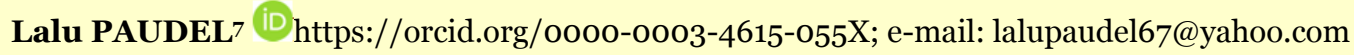
Nirusha SHRESTHA7 iD http://orcid.org/oooo-0oo1-6959-3076; e-mail: shresthanirusha2@gmail.com *Corresponding author 1 Institute of Mountain Hazard and Environment, Chinese Academy of Sciences, Chengdu 610041, China 2 University of Chinese Academy of Sciences, Beijing 100049, China 3 Central Department of Environmental Science, Tribhuvan University, Kathmandu 44613, Nepal 4 CAS Center for Excellence in Tibetan Plateau Earth Sciences, Beijing 10o101, China 5 China-Pakistan joint Research Center on Earth Sciences, Islamabad 45320, Pakistan 6 Faculty of Geo-information Science and Earth Observation, University of Twente, Enschede 7500 AE, The Netherlands 7 Central Department of Geology, Tribhuvan University, Kathmandu 44613, Nepal

Citation: Dhakal S, Cui P, Su LJ, et al. (2020) Landslide susceptibility assessment at Kathmandu Kyirong Highway Corridor in pre-quake, co-seismic and post-quake situations. Journal of Mountain Science 17(11). https://doi.org/10.1007/s11629-020$6314-x$

(C) Science Press, Institute of Mountain Hazards and Environment, CAS and Springer-Verlag GmbH Germany, part of Springer Nature 2020

Erratum to: J. Mt. Sci. (2020) 17(11): 2652-2673

https://doi.org/10.1007/s11629-020-6314-x

The "ALOS PULSAR DEM" is incorrect in the original article. The correct one should be "ALOS PALSAR DEM”.

The online version of the original article can be found at https://doi.org/10.1007/s11629-020-6314-x. 